\title{
The school-enterprise docking accounting professional training mode research under the multi-dimensional perspective
}

\author{
Yan Jia \\ Shandong Women's University, Jinan, Shandong Province, China, 250300, China
}

Jiayan1753@163.com

Keywords: Multidimensional angle; School-enterprise docking; accounting personnel.

\begin{abstract}
With the rapid advances in the development of market economy and social enterprises for talent Urgent needs, the importance of accounting personnel in enterprises has become increasingly prominent. This requires schools and businesses were cultured docking mode of accounting personnel, school-enterprise docking formed between schools and enterprises, between enterprises and the government, the close relationship between the school and the government, schools and enterprises in the multi-dimensional angle butt firmer foundation training familiar with the various national laws and regulations, business and strong professional accounting personnel.
\end{abstract}

\section{Introduction}

Currently, a number of schools in order to meet the rapid development of market economy, continue to carry out educational reform, to explore their own school education with school characteristics. Such as "school-enterprise integration of teaching" mode, the "Order" training mode "multi-card multi-skilled" training mode " $2+1$ " or " $3+1$ " training mode, though different names, study its essence is to develop a suitable government, enterprises need qualified accounting personnel faster. Such training methods, to some extent eased the demand for accounting professionals, and increased efforts to train school personnel in accounting, but in particular the implementation process, there are still some problems.

\section{Status accounting personnel training mode Polyenes}

The current model is the government's supervision and help businesses and schools docking schools to train students in practical ability as a starting point for students and ultimately successfully employed for the purpose of training the training mode has its own school characteristics. Companies can address the quantity and quality of talent on the bottleneck problem in the ongoing reform of expansion. Students can combine study and work two-, learning by doing, learning to do, found wanting at work, constant improvement, so that their rapid growth as application-oriented talents.

The current training mode, because of the parties, there is a different problem. Perform some college enrollment, there has been student dormitories, cafeteria, library and other teaching resources inadequate investment, teachers and serious imbalance situation, in this case, the student will be given away internship, relieve school stress. Some companies in order to ease the employment pressure, high-volume receiver in school internship posts, but it is not a professional accountant or accounting related professional practice, there have been sales personnel, service personnel and other positions. As the economy continues to develop, the government enterprise, the school will continue to support efforts to abate, the lack of strict government regulation, there has been between enterprises and schools, "hit it off" state. This requires, enterprises accounting personnel training schools continue to improve their core competitiveness, school by helping companies make full use of corporate facilities, equipment, laboratories and other train their students to enhance practical skills training for teachers, and gradually improve the competitiveness of the school. 


\section{The problems of accounting personnel training business process}

Corporate awareness of sincere cooperation with universities need to be further strengthened, many enterprises in order to meet labor needs, considering the cost of the employer, then the introduction of internships for students, but arrange for students to buckle down to some of the odd jobs post teaching jobs; accounting positions with a certain degree of particularity, large some enterprises in order to protect their own business data and internal data, do not agree to participate in internships to students in real business accounting work among the students appeared to sales positions or service staff positions; in a market economy, companies will always be financial management will maximize the benefits of a target company, facing school-enterprise cooperation proposed by universities, many companies tend to focus on fame, passively, formally agreed to accept students without any work experience, but not provide a true post teaching jobs, college stimulate enterprises to truly be no school-enterprise cooperation "contact.".

\section{School-enterprise-based training model butt accounting construct multidimensional perspective}

Do Science and Arts college accounting students fully protect the part of the business demand for science and engineering students, and the students basic accounting, intermediate financial accounting, advanced accounting, small business accounting , tax accounting , financial management, economic law courses taught at the same time, periodic counseling students to test out the relevant qualification certificates and professional certificates in the study of theoretical knowledge, and obtain the certificate, while the organization of practical training students to integrate, organize students with banks, tax authorities simulation work, the final stage will be given away enterprises student internships, internship ended, double -elect recruitment activities of enterprises and students, arrange student internships during their college will ease the pressure on the school to some extent , arrange for students and corporate two-way Council will raise the pressure on college students. Try to do a combination of academic and professional status, according to the market economy, set the "CPA class" "intermediate accounting class" "Enterprise Financial Officer Class" and so on, custom appropriate accounting personnel according to business needs training program. University faculty can be integrated into their business among the annual winter summer, you can arrange the accounting profession classroom teachers to post teaching enterprise testing exercise, and develop appropriate regulations and assessment mechanism, enhance business practices classroom teachers work experience and enthusiasm to improve the practical skills of teachers, in order to have the ability to use more adequate to the usual practice of teaching. Theoretical knowledge can then be taught in the classroom in the school classroom simulation training after the end of the operation, the operation is completed to guide students through practice , can solve the original single classroom teachers teach , students passively listen, to teachers and students through hands-on interaction.

Anchored to the school-enterprise cooperation, corporate accounting internship receiving college students, while practical skills training, integration of training and teamwork training execution, and after the end of the internship, selected for recruitment under the double further training students to clear business objectives, corporate culture and are familiar with the rules and regulations. Train to become their employees, companies will feel in the university staff and gradually develop a passion for business and loyalty degree.

Enterprises can use the advantages of universities financed, the total is well known universities with expertise in cutting-edge talent, and you can take advantage of University Teachers corporate staff training. Colleges with adult education, Self-education, college, undergraduate, graduate, $\mathrm{PhD}$ taught multi-level three-dimensional way, you can train for employees, and ultimately makes the employees in education levels and knowledge levels have improved full three-dimensional....

Companies can use college campus practice base by university teachers with professional titles on the professional skills and knowledge of the industry training, expertise can be identified in the same 
industry, the two sides reached a gain of schools and enterprises at the same time win to improve the visibility and social influence companies within the industry.
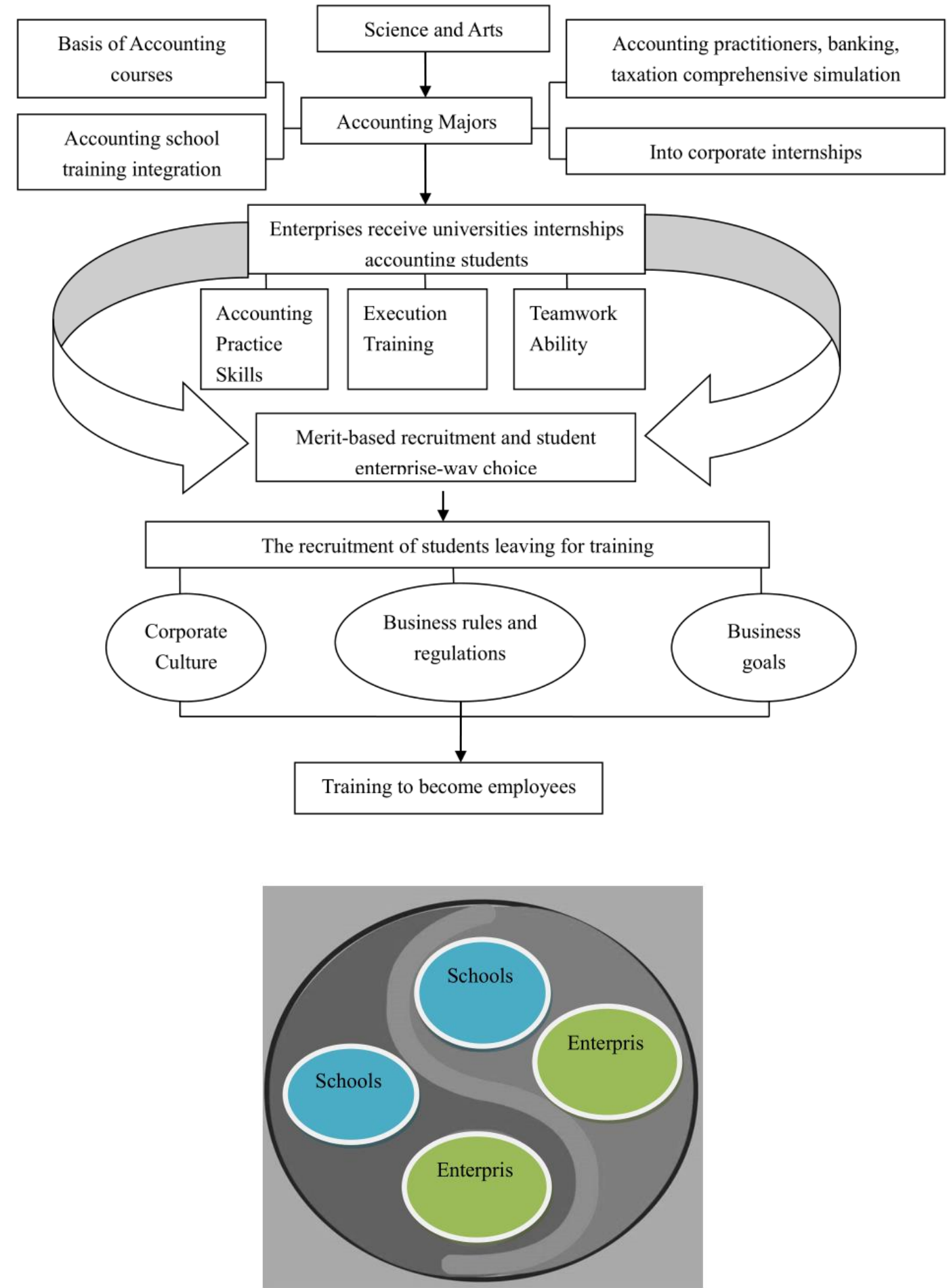

Government, universities, businesses three are interrelated, inseparable from the interests of the government between universities and enterprises as an important role, the government should provide security funds and institutional encouragement for enterprise and university docking, the potential for mining enterprises to school-enterprise cooperation, and effective incentives to form community through a variety of school-enterprise incentives. The process of regulation of school-enterprise cooperation, long-term protection of school-enterprise cooperation, sustainable manner, for the government, over time, will ease the difficult problem of college student employment, social stability have some positive effect. Enterprises according to their own needs in colleges and universities will form the cradle of accounting personnel training, will form accounting personnel incubators, help 
enterprises to improve the core competitiveness of the enterprises bigger and stronger, and constantly improve the economic efficiency of enterprises, and increase the amount of tax form economic growth.

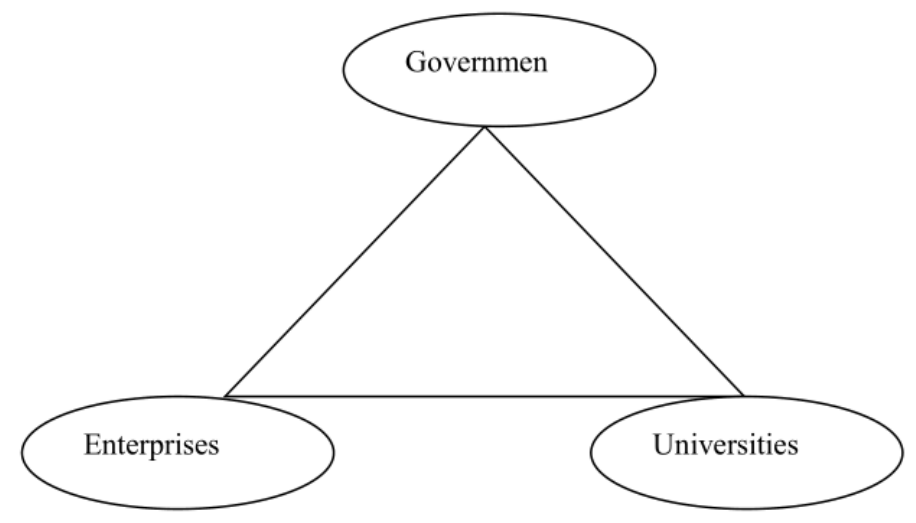

\section{Conclusions}

A lot of company along with the development of Chinese economy, the demand for accounting talents is very large. Of institutions of higher learning accounting professional talents has become the important applied talents, it's high standards and high requirements are put forward for the accounting personnel, to the accounting personnel training, not only attaches importance to theoretical knowledge, but also attaches great importance to the students' ability of practice ability training, etc. Colleges and universities on the basis of itself of accounting talents training target, increase the close degree of combination between higher vocational colleges. Through "university-enterprise cooperation and work-integrated learning" to make the theory and practice of accounting teaching reform of colleges and universities together, develop to adapt to all kinds of industry needs, better qualified for all kinds of industry accounting work applied accounting talents with high skill.

\section{Acknowledgements}

This work was financially supported by the focus of corporate training and employee education research of Shandong province (2014-065).

\section{References}

[1] Ding Hua. College Accounting Application Personnel Training mode [J] Accounting communications, 2011, 22: 29-30.

[2]Yao Yong. Regular undergraduate school of Local colleges and enterprises docking personnel training model $[\mathrm{J}]$ Nanyang Normal University, 2012, 07: 104-106 + 109.

[3] Shang Bihui. Establish school-enterprise cooperation skills-based training model study [D]. Southwest Jiaotong University, 2012.

[4] He Yurun,Li Xiaohui. Our College Accounting Personnel Training Mode - Based on the US ten universities of field research in Accounting Education [J]. Accounting Research, 2013, 04: 26-31+95.

5] Zhang Ying. Based on the "school-enterprise students" tripartite interaction Tourism Management Professional Training Research and Practice [J]. Jincheng Vocational and Technical College, 2013, 05: 30-33.

[6] Fu Huailiang. Research local university cooperation between schools and enterprises applied talents training mode [J] Heihe Jurnal, 2013,11: 165-167.

[7] Jin Rengui, Wang Lei,Han hui. Research "school-enterprise cooperation" with innovative training model [J] Technology market economy, 2010,12: 81-82. 